\title{
Rebalancing Religious Policy and the Concept of Public Sphere: Indonesia Cases
}

\author{
Petrus Richard Sianturi ${ }^{*}$ \\ Master of Legal Science Program, Gadjah Mada University, Yogyakarta, Indonesia \\ Josua Navirio Pardede** \\ Master of Legal Science Program, Gadjah Mada University, Yogyakarta, Indonesia
}

\section{Septian Dwi Riadi ${ }^{* * *}$}

Master of Legal Science Program, Gadjah Mada University, Yogyakarta, Indonesia

\begin{abstract}
As the largest Muslim country, Indonesia is on the way to balancing the order of its people, their religious practice, and how these two are influencing the public sphere. There is an existing regulation called Anti-Blasphemy Law which contains any rule to guarantee that religion and the public sphere do not contradict from one to another. Related to it, this research found that in this digital era with an advanced development on technology, some factors potentially create any form of manipulation on religion which comprises religion itself, social dynamic, and legal instrument. This form of manipulation has also triggered the advancement of the interdependency discourse on religion and the public sphere. In the context of Indonesia, by its characteristic, to separate religion and the public sphere will only create other problems among religious people. Using normative legal research, this paper aims to look at the relevance of the Anti-Blasphemy Law to the socio-structural conditions of Indonesian society. In this research, it is argued that religion and the public sphere (state) should be placed through a form of functional differentiation concept, and found that there is an interdependent relationship between religion and the public sphere, nevertheless, AntiBlasphemy Law failed to create and maintain this relation. Hence, legal reform on the AntiBlasphemy Law has become a necessity in ensuring a balanced and harmonious (state) religious life.
\end{abstract}

Keywords: Anti-Blasphemy law; Functional differentiation; Manipulation of religion; Technology advancement.

\section{INTRODUCTION}

The historical journey has placed religion as a conceptual system that cannot be separated from the development of human civilization. In the last few centuries, several ideas and thoughts have placed religion as a natural phenomenon experienced by mankind that is fundamental in almost all cultures and history. ${ }^{1}$ Academically, this argument is supported by some facts on the occurrence of intellectual developments in the concept of religion such as in the fields of sociology and anthology by trying to show

\footnotetext{
*Email : richardsianturi@mail.ugm.ac.id and rich.sianturi@gmail.com

${ }^{* *}$ Email/Corresponding Author: josuanavirio1996@mail.ugm.ac.id and josuanavirio1996@gmail.com

***Email: septiandwiriadi@mail.ugm.ac.id and se ptiandwiriadi@gmail.com

${ }^{1}$ Brent Nongbri, Before religion: a history of a modern concept (New Haven; London: Yale University Press, 2013), I.
} 
the function and development of religion. ${ }^{2}$ Not only in the realm of intellectual notion alone but also in the space of human observation, namely society, issues related to religion will continue to generate new discourses and arguments, in this case, the Indone sian people.

The discussion on the relation between religion and state in Indonesia was always found interesting. There are at least two reasons for this statement: First, Indonesia is a country based on the idea of God Almighty, as contained in the first precepts of Pancasila as the basis of state philosophy (philofische grondslag), ${ }^{3}$ and further manifested in Article 29 paragraphs 1 and 2 of the 1945 Constitution of the Republic of Indonesia (hereinafter, Indonesian Constitution) which more clearly shows the direction of the development of religious national law. ${ }^{4}$ Second, Indonesia is now the largest Muslim country in the world through its population number. It is also undeniable that all acting governments from time to time could not reject the existence of religious values to develop and run every (public) policy. However, the way to run a state in balanced and proportional differentiation in where and when religion should act and where and when not, has not always been easy. Indonesia faces many challenges in the effort of balancing religion and the public sphere issue. At the same time, some regulations have been created and made new problems at hand. As this research is focused to examine the existence of Presidential Decree No. 1/PNPS/1965 concerning the Prevention of Abuse and/or Blasphemy of Religion (hereinafter, Anti-Blasphemy Law), 5 we found that the implementation of the law has even made "unintended consequences" to the socie ty itself. 6

2 Robert Segal, "Theories of Religion," in The Routledge Companion to the Study of Religion, ed. John R Hinnels (London; New York: Routle dge, 2009), 49-60.

${ }^{3}$ Soekarno stated that the philosfische grondslag as a "fundamentals, philosophy, deepest thoughts, souls, deepest desires for the building of an independent Indonesia, eternal and everlasting", Soekarno in Saafroedin Bahar, Ananda B. Kusuma \& Nannie Hudawati eds., Risalah Sidang Badan Penyelenggara Usaha Persiapan Kemerdekaan Indonesia (BPUPKI)-Panitia Persiapan Kemerdekaan Indonesia (PPKI) 28 Mei 1945-22 Agustus 1945. Ed. III. Cet. 2 (Jakarta: Sekretariat Negara R.I., 1995), 41.

4 Article 29 of the 1945 Constitution affirms: (1) The state is based on the One Almighty God; (2) The state guarantees the inde pendence of every resident to embrace their respective religions and to worship according to their religion and beliefs. Therefore, Bagir Manan, Ali Abdurahman \& Mei Sussanto stated that, "as a philosfische grondslag, Pancasila should be embodied in all aspects of the nation's life, including the field of law. Therefore, it is a necessity and necessity that the national law of Pancasila contains religious content as the embodiment of the precepts of the One Godhead, as the moral foundation of the national legal system. Bagir Manan, Ali Abdurahman \& Mei Sussanto, "Pembangunan Hukum Nasional yang Religius: Konsepsi dan Tantangan dalam Negara Berdasarkan Pancasila", Jurnal Bina Mulia Hukum 5, No. 2 (2021): 186-187.

5 There are some English translations and abbreviations for this presidential degree, e.g. Law on Prevention of Religious Defamation and PNPS Law.

6 What is meant by "unintended consequences" here is the impact that occurs outside the purpose of the establishment of the PNPS law or Anti-Blasphemy Law itself, which aims to secure the legal interests of the religion adhered to in Indonesia.Hwian Christianto, "The Significant Impact of Law No. 1/PNPS/ 1965 for The Freedom of Religion", Jurnal Yudisial, 6, No. 1 (2013): 4. Or if we refer to the opinion of Oemar Seno Adji, "the existence of the blasphemy law aims as a defense mechanism against Pancasila with the precepts of Belief in the One Supreme God from attacks by mocking words. Oemar Seno 
In its journey, the anti-blasphemy provision was only used in eight cases in its first four decades, but the verdicts increase to 125 cases during President Susilo Bambang Yudhoyono's decade in power, from 2004 to 2014. Twenty-three (23) other people have also been sentenced since President Joko Widodo took office in $2014 .{ }^{7}$ Then during the initial period of the pandemic (January-May 2020), there have been 38 cases of blasphemy. ${ }^{8}$ Some phenomenal cases related to blasphemy such as the case of the Lia Eden sect in 2008,9 Then the case of the former Governor of DKI Jakarta, Basuki Tjahaja "Ahok" Purnama in 2016,10 or the mosque sound system protest by Meiliana in North Sumatra on 2016.11

In the scope of legal science, the discourse related to Anti-Blasphemy Law itself is dominated by studies of penal, Islamic, and constitutional law, such as those relating to criminal offense ${ }^{12}$, criminal liability ${ }^{13}$, judicial revie $^{14}$, and Islamic concepts ${ }^{15}$. Hence, the socio-philosophical approach offered in this research also seeks to contribute to the diversity of thought in perceiving an issue related to PNPS Law or Anti-Blasphemy Law.

This writing is normative legal research. It uses secondary data including primary, secondary, and tertiary legal sources that are processed with quantitative data. Those sources and resources are analyzed descriptively to explain the actual and contextual reality between the three main components namely law, religion, and society in Indonesia.

Adji. Perkembangan Hukum Pidana dan Hukum Acara Pidana Sekarang dan di masa jang akan Datang (Jakarta: Pantjuran Tujuh, 1984), 297.

7 Andreas Harsono, "Korban Penerapan Pasal Penodaan Agama di Indonesia", https://www.hrw.org/id/news/2018/10/25/323701

8 Berita Satu, "YLBHI: Januari-Mei 2020 Terjadi 38 Kasus Penodaan Agama" https:/ / www.be ritasatu.com/nasional/670519/ylbhi-januarimei-2020-terjadi-38-kasuspenodaan-agama Tempo.

"Be gini Perjalanan Metamorfosa Lia Eden", https:/ /nasional.tempo.co/read/672566/ begini-perjalanan-metamorfosa-lia-eden

10 Detik News, "Soal Al Maidah 51, Ahok: Saya Tak Berniat Melecehkan Ayat Suci Alquran", https://news.de tik.com/berita/d-3315203/soal-al-maidah-51-ahok-saya-takberniat-melecehkan-ayat-suci-alquran

${ }^{11}$ BBC News Indonesia, "Banding Meiliana, yang divonis penjara 1,5 tahun karena keluhkan suara azan, ditolak Mahkamah Agung", https://www.bbc.com/indonesia/indone sia-47859654

12 Kurnia Dewi Anggraini, "Penafsiran Tindak Pidana Penodaan Agama dalam Perspektif Hukum", Era Hukum: Jurnal Imiah Ilmu Hukum, 15, No. 2 (2017): 267-268; \& Hijrah Adhyanti Mirzana, "Ke bijakan Kriminalisasi Delik Penodaan Agama", Pandecta 7, No. 2 (2012): 147-148.

13 Ajie Ramadan, "Aspek-Aspek Konstitusional Penodaan Agama Serta Pertanggungjawaban Pidananya di Indonesia”, Jurnal Konstitusi 15, No. 3 (2018): 616-617.

14 Yayan Sopyan, "Menyoal Kebebasan Beragama dan Penodaan Agama di Indonesia", Jurnal Cita Hukum 3, No. 2 (2015) 195-196.

15 Muhammad Dahri, "Tindak Pidana Penodaan Agama di Indonesia: Tinjauan Pengaturan Perundang-undangan dan Konsep Hukum Islam", At-Tafahum: Journal of Islamic Law 1, No.1 (2017): 57-58. 


\section{RESULT AND ANALYSIS}

\subsection{Religion and Society in Indonesia}

In the Indonesian context, religion and society have a unique relationship that is correlated with each other. From the historical aspect, the discourse of both has existed long before Indonesia's independence, when Dutch legal experts. Lodewijk Willem Christian van den Berg introduced the theory of "receptio in complexu", which states that religious law (Islam) is accepted as a whole by the surrounding community who embraces that religion. In short, customary law follows the religious law embraced by the indigenous people. ${ }^{16}$ However, this theory was refuted by Snouck Hugronje and Van Vollenhoven through their 'receptie' theory. According to Hugronje, Islamic law can be applied as long as it does not conflict with or has been accepted by customary law. That is, Islamic law follows the customary law of the surrounding community. ${ }^{17}$ This theoretical discourse shows that the interaction between religion and state policy is not a new phenomenon in Indonesia and has been recorded in the history of the nation's journey. Both internally and externally, religion is a component that can produce a wide influence on various other social components in society. The most recent national census on religion conducted in 2018 produced religious demographic figures in Indonesian society. From the total 266.534.836 inhabitants of Indonesia, Islam became a religion with a majority of 231.069 .932 persons $(86,69 \%$ - eighty-six point sixty-nine percent), followed by Protestant 20.246.267 persons $(7,59 \%$ seven point fifty-nine percent), Catholic 8.325 .339 persons $(3.12 \%$ three-point twelve percent), Hindu $4.646 .357(1.74 \%$ - one point seventy four percent), Buddhist 2.062.150 persons $(0.77 \%$ - zero point seventy seven percent), Confucianism 71.999 persons, and penghayat kepercayaan believers in God 112.792 persons 18 The composition shows how Indonesian's religious awareness is not only formed from one dogmatic awareness but consists of diverse elements including various forms of religious practices outside the six religions recognized by the state or known as indigenous beliefs, which is based on data from between 12 million to 20 million. ${ }^{19}$

Related to that, in the education field, religion influences how the orientation of the construction of the Indonesian education system can work. Data from the Ministry of Religious Affairs shows the number of

16 Soerojo Wignjodipoero. Pengantar dan Asas-Asas Hukum Adat (Jakarta: Haji Masagung, 1990), 28.

17 Muara Hutagalung. Hukum Islam dalam Era Pembangunan (Jakarta: Indo Hill Co, 1985), 19.

18 Ministry of Religious Affairs, "Statistics of the Citizen by Religion in Indonesia," http:// https://data.kemenag.go.id/agamadashboard/statistik/umat

19 There are no precise data that provides the number of the population who live in what so-called indigenous belief. There is data that says 12 million people from the Library of Congress Global Legal Monitor, "Indonesia: Constitutional Court Opens Way to Recognition of Native Faiths," www.loc.gov/law/foreign-news/article/indonesiaconstitutional-courtope ns-way-to-recognition-of-native-faiths. There is also data shows 20 million people, compared to the US State Department, "International Religious Freedom Report for 2016, 2017," www.state.gov/j/drl/rls/irf/2016 
faith-based education, such as Islamic education continues to increase every year. Since 1977, the number of pesantren (Islamic boarding schools) which only amounted to 4,195 with the number of students around 677,394 people continued to increase in the next decade as in 1985 which amounted to 6,239 units and the number of students around 1,084,801 people. In 1997, the ministry noted the number of pesantren had increased by 9,388 and increased of students by $1,770,768$. Then in 2016 , the re were already 28,194 pesantren spread both in urban and rural areas with 4,290,626 students. ${ }^{20}$ No less than pesantren, Islamic-oriented formal education has also a relatively high number, wherein 2018 there was 47,221 Islamic-oriented formal education in Indonesia with a ratio of one school to 4,387 students. ${ }^{21}$ In addition to Islamic education, other religions such as Catholicism and Protestantism also have educational institutions at various levels that have an educational orientation by their religious values. Data shows that there are around 3821 schools with a Catholic educational orientation and more than 5000 for Protestantism with a total number of students of $723,022 .{ }^{22}$

In the political field, religion has a strategic position and becomes a medium for group participation and aspirations in democratic life. It is worth noted that there are certain political parties such as PKS, PKB, PPP, and PAN who declare themselves to have a religious orientation in carrying out their respective political activities. In the same line, the trend of religious influence in electing leaders was reiterated in the past 2017 DKI Jakarta regional election, where the majority of voters based their choices for "same religion" reasons by 34.9\% (thirty-four point nine percent) outperforming other reasons such as "proof of real work" with $13.2 \%$ (thirteen point two percent) and "programs offered" only by $7.2 \%$ (seven point two percent). ${ }^{23}$ This figure shows the magnitude of the influence of religion in the political matters of society, where religious identity is still considered as the "mouthpiece" of the ideal group's aspirations in democratic activities in Indonesia.

\subsection{Social Reality and Religion Today}

Data shows the Information, Communication, and Technology Development Index (IPTIK) in Indonesia continues to increase every year, wherein 2017 IPTIK Indonesia is at 4.99, an increase from 2016 with an index of 4.34. This index shows the increase in technological development in Indone sia, especially communication and information by looking at three main indicators namely access and infrastructure, utilization, and

20 Directorate General of Islamic Education, Sistem Informasi dan Humas Seketariat Direktorat Jenderal Pendidikan Islam: Annual Report. (Jakarta: Ministry of Religious Affairs, 2017), 13.

${ }^{21}$ Azmil Tayeb, Islamic Education in Indonesia and Malaysia: Shaping Minds, Saving Souls, (Jakarta: Routledge, 2018), 12.

22 Persekutuan Gereja-Gereja di Indonesia, "Christian School Condition in Indonesia," https://pgi.or.id

${ }^{23}$ Burhanuddin Muhtadi . Populisme Politik Identitas \& Dinamika Elektoral: Mengurai Jalan Panjang Demokrasi Prosedural (Malang: Intrans Publishing, 2019), 16. 
expertise. ${ }^{24}$ This fact also has an impact on religion as part of the social reality of Indonesian people who experience various shifts to cyberspace. Such social dynamics had created a trend in Indonesian society that tried to find spiritual fulfillment in cyberspace. Data released by The National Counterterrorism Agency (BNPT) shows that 9.89\% (nine point eighty-nine percent) of Indonesians use social media to search for and disseminate content about religion. The figure was formed from the composition of some information such as "the existence of God" of 43.91\% (fourty three point ninety-one percent), "the power of God" of 40.31\% (forty point thirty one percent) and "the story of the saints" of $36.72 \%$ (thirty six point seventy-two percent). ${ }^{25}$

Besides, in general, in 2017 Indonesian people have an interest in religious content on the Internet by $41.55 \%$ (forty one point fifty-five percent) in the social information category. ${ }^{26}$ These conditions led to a situation where traditional religious authorities became a choice. Religious leaders to religious institutions that were previously the main guideline in religious life in society have experienced a shift in position due to the easier and satisfying access to religious content and information on social media. This situation can lead to conditions where people easily echo information (related to religion) without verifying or falsifying the information based on merely subjective-emotional needs or known as the "Post-Truth" phenomenon.

The formation of a "Post-Truth" society led to the emergence of various manipulative efforts towards religion in cyberspace, especially in the form of hoaxes consisting of misinformation and disinformation related to religious content in cyberspace. In 2017, at least 800,000 sites spread hoax news, and in the same period, public report on the negative religious content was ranked second with a total of 15,818 contents and/or sites. ${ }^{27}$ Then, from August 2018 to April 2019, there were 1224 cases of hoax spreading where religious-themed hoaxes were ranked 6th with a total of 81 hoax contents. ${ }^{28}$ However, the data also shows that hoax content related to religion does not only standalone but is also manipulated for political

${ }^{24}$ Badan Pusat Statistik, "Development Index: Information and Communication Technology (IPTIK) Indone sia," http:// bps.go.id

25 Badan Nasional Penanggulangan Terorisme, Social Media Dissemination Index, (Jakarta: Badan Nasional Penanggulangan Terrorism, 2019).

${ }^{26}$ Indone sian Internet Service Providers Association, "Penetration and Behavior of Internet User in Indonesia," http:// teknopreneur.com

${ }^{27}$ Ministry of Information and Communication, 'There are 800.000 Hoaxes' Sites in Indonesia," http:/ / kominfo.go.id

28 Various cases of religious-based hoaxes that have occurred, especially before the regional head election season, as happened in 2018, hoaxes on mosque construction by the Governor of DKI Jakarta, hoaxes on religious blasphemy by Ahok, hoaxes on large religious-based demonstrations and hoaxes against religious leaders (Ulama). BBC News Indonesia, "Hoax seputar kasus Ahok, FPI, 4 November", https://www.bbc.com/indonesia/trensosial-37843842 
purposes with the presence of 43 religious-political contents throughout, for example, in 2019 as a political year. ${ }^{29}$

Every form of manipulating religion to accommodate certain interests is not only supported by technological advances and extensive communication flow. The law as part of essential components in society also plays a role in such increasingly vulnerable manipulative acts. It is known that in 2018 there are around 22 discriminatory regulations with three main groups of types of policies namely the necessity to carry out "congregational prayers", the obligation to dress or religious attributes, and the obligation to read the Al-Quran. The majority of these policies are circular policy (15 policies), written regional head policy (1), unwritten regional head policy (2), unwritten school principal policy (1), school code of conduct (1), draft regional law (1), and code of conduct competition (1). ${ }^{30}$

Also, there are quite controversial legal instruments such as the AntiBlasphemy Law in Indonesia's national legal system with legal construction aimed at establishing "gray" areas, namely religion. This anomalous legal product was then followed by, among others, the presence of a Joint Decree (SKB) of 2 (two) Ministers ${ }^{31}$ which became phenomenal with the regulation regarding the need for a minimum number of permits for a certain community to build their houses of worship that harmed the space for religious freedom in Indonesia. In its practice, the Joint Decree is a form of discrimination against certain religious groups, particularly the minoritie ${ }^{32}$ The existence of various legal instruments becomes a kind of manipulation of religion. Where this juridical reality opens up opportunities for control efforts over religion to accommodate certain interests in the law enforcement space.

To sum up the issue, this research found that religious matters in the public sphere have led to the creation of an interdependency relation between religious people along with its social dynamic and the existence of religion through legal instruments such as the existing Anti-Blasphemy Law. As these two matters are now running at the same time (tempus) and place (locus), it is clear to depict that such social dynamics have led to the

29 Ministry of Information and Communication, "Ministry of Information and Communication Findings: Hoax is Most Se parated in April 2019," http:/ /kominfo.go.id

30 Wahid Foundation, "Membatasi Para Pelanggar: Laporan Tahunan Kemerdekaan Beragama Berkeyakinan Wahid Foundation 2018," http://wahidfoundation.org

${ }^{31}$ Surat Keputusan Bersama 2 (Dua) Menteri (Joint Decree of Two Ministers) has the official name "Joint Ministerial Regulations (PBM) No. 9 and 8 of 2006 on Guidelines for the Implementation of Duties of Regional Heads/Deputy Heads in the Maintenance of Religious Harmony, Empowerment of Religious Harmony Forums, and Establishment of Houses of Worship", is a regulation that provides a number of provision for the establishment of places of worship in Indonesia, such as a list of names of people who permit the establishment, written recommendations from the head of the district/city religious de partment office to the written recommendations for religious communication forums. In this context, the existence of the 2 Ministerial Decree is another example of legal intervention against religion which tries to design the religious life of the community as de sired, yet it creates other new problems in the building process of the houses of worship.

${ }_{32}$ Nella Sumika Putri, "Pelaksanaan Kebebasan Beragama di Indonesia (External Freedom) Dihubungkan Ijin Pembangunan Rumah Ibadah", Jurnal Dinamika Hukum 11, No. 2 (2011): 241. 
manipulation of interpreting, approaching, and/or practicing religion. This research argues that the above condition constructed a unique interdependent relationship between the two that support one another.

\subsection{Anti-Blasphemy Law: An Overview}

Indonesia is still maintaining Presidential Decree No. 1/PNPS/1965 concerning the Prevention of Abuse and/or Blasphemy of Religion which is known as Anti-Blasphemy Law. Despite many controversies that have been made during the enactment of this law, Indonesia is still le gally recognized the need for such law. As stated in point 2 (two) of the elucidation, the law aims to "protect" state and society from any mystical belief and/or practice of such belief that threatening the so-called certain "recognized" religion (Islam, Protestant, Catholicism, Hinduism, Buddhism, and Confucianism). In essence, the law prohibits statements or activities that insult a recognized religion or intend to prevent someone from adhering to such a religion. The law also forbids distributing information designed to spread hatred or dissension based on ethnicity, religion, or race. Under these provisions, individuals can be prosecuted for blasphemous, atheistic, or heretical statements. ${ }^{33}$

However, this provision seems contradicts to the provision of Article 29 of the Indonesian Constitution which guarantees that Indonesian people have the right and freedom to live and embrace the belief which they choose. It is understandable that during its enactment for more than 50 years, the law has been challenged for judicial review before the Constitutional Court. Through the ambiguity of the Anti-Blasphemy Law and the existence of Article 29 of the Indonesian Constitution, consequently, other religions such as Judaism, Zarathustranism, or Taoism, including all mystical beliefs that exist in Indonesia are not banned. However, things written normatively have not always been in line with the practical fact were the discrimination of such belief out of the recognized religion had happened massively.

According to Amnesty International, from 2005 to 2014, there were at least 106 individuals sentenced by Anti-Blasphemy Law. These cases were in various forms. For example, in East Java, Tajul Muluk was sentenced to four years in prison for being deviant as he is a membe $r$ of Shiite. ${ }^{34}$ In Central Java, Andreas Guntur, the leader of the Divine Majesty Mandate

33 Paul Marshall, "The Ambiguities of Religious Freedom in Indonesia." The Review of Faith \& International Affair 16, No.1 (2018): 85-95.

34 Tajul Muluk a.k.a Ali Murtadha was legally and convincingly proven to have committed blasphemy with a sentence of 2 (two) years in prison. Sampang District Court Decision No. 69/PID.B/2012/PN.Spg, 2012, p. 1-2. Regarding this decision, one of the NGOs, the Commission for Disappeared Persons and Victims of Violence (KONTRAS) stated that the decision taken by the judge against Tajul Muluk was a form of careless justice by not assessing the justice substance contained in the evidence that presented at the trial, this statement can be seen in Kontras, "Peradilan Sesat Tajul Muluk", https://kontras.org/2012/07/16/peradilan-sesat-tajul-muluk/ 
sect, was sentenced to four years in prison for his faith. ${ }^{35}$ In 2012 , the same year of Andreas Guntur, Sebastian Joe was sentenced to five years in prison by the Bandung High Court on the allegations of the Islam Defenders Front (FPI) who stated Joe had insulted Islam and created a new religion. ${ }^{36}$ In 2017, Basuki Tjahaja Purnama, popularly called and known as 'Ahok', was charged with blasphemy under Criminal Code and AntiBlasphemy Law and was sentenced to two years in prison. ${ }^{37}$

All controversies resulted from the Anti-Blasphemy Law made some groups of people challenged the law before the Constitutional Court through a judicial review mechanism. In 2009, groups of non-governmental organizations (NGOs) and individuals requested the court to revoke the Anti-Blasphemy Law by arguing that the existence of this law has made more problems in religious harmony than to give benefits to society. They also argued that the law harmed the protection and enforcement of human rights as regulated in the Indonesian Constitution. The plaintiffs also stated that the regulation, especially to Articles 1 and 2, had made multiinterpretation on the concept of religion and/or faith and that the provisions contained in the Anti-Blasphemy Law are contrary to the principles of the rule of law, with the reason that the law was made by the old order regime when the President has the authority to make laws. The law has been deemed incompatible with the spirit of the constitution because the power to make laws is in the hands of the Peoples' Representative Council (DPR) is contained in Article 20 paragraph (1), while the government only has the right to submit a bill to the DPR according to Article 5 paragraph (1). ${ }^{38}$

They concluded that the existing Anti-Blasphemy Law had decreased the guarantee and protection of one's right directly or indirectly. In their point of reason to challenge the law, such a situation impacts the relationship among individuals in the society from data analyzed in this paper. To support their arguments, one of their witness expert to the court

35 The Klaten District Court decided that Andreas Guntur had violated Article 156a of the Criminal Code which was sourced from the PNPS Law or Anti-Blasphemy Law, and must be sentenced to imprisonment for 4 (four) years. Putusan Pengadilan Tinggi Semarang No. 98 / PID / 2012 / PT.SMG-Andreas Guntur Wisnu Sarsono, 2017, p. 11-12.

36 As a result of his comments on Facebook, which were considered intentionally and without rights to spread information to create feelings of hatred/hostility towards individuals and certain community groups based on SARA/Suku, Agama, Ras, Golongan (Ethnicity, Religion, Race and Inter-Group), the Ciamis District Court sentenced him to 5 (five) years in prison. Sebastian Joe bin Abdul Hadi. Ciamis District Court Decision No. 278/Pid.Sus/2012/PN. Cms-Se bastian Joe, 2012. 4.

37 The North Jakarta District Court in its decision stated that the defendant Ir. Basuki Tjahaja Purnama a.k.a Ahok was legally and convincingly proven guilty of committing a criminal act of blasphemy and Article 156a of the Criminal Code and then sentenced the Defendant to imprisonment for 2 (two) years. Putusan Pengadilan Negeri Jakarta Utara No. 1537/ Pid.B/2016/PN.Jkt Utr-Ir. Basuki Tjahaja Purnama a.k.a Ahok, 2017, 2.

38 The NGOs are IMPARSIAL, ELSAM, PBHI, DEMOS, Perkumpulan Masyarakat Setara, Desantara Foundation, and YLBHI. There are also groups of prominent figures; former Indonesian president K.H Abdurrahman Wahid, Prof. Dr. Musdah Mulia, Prof. M. Dawam Rahardjo and K.H. Maman Imanul Haq. Read Constitutional Court Decision No. 140/PUU-VII / 2009, 1-3. 
is W. Cole Durham Jr, Emeritus Professor of Law at the J. Reuben Clark Law School of Brigham Young University, who stated that the International Covenant on Civil and Political Rights (ICCPR) has not limited any form of religion to the "big religion" as exist today, but also guarantee the protection of all religions as a "sub-division" of the big religion, any movement of new religious practice, Folklore religion, etc. ${ }^{39}$

In this context, Wahid Foundation research data in 2018 need to be considered. Wahid Foundation released 276 violations on freedom of religion and belief. Most violation acts were carried out in the form of punishment based on religion/belief amounting to 48 actions, and religious / belief heresy amounting to 32 violations. This trend has increased from the previous year which amounted to 26 acts for criminalization and 19 actions for heresy/religion. The strengthening of identity politics and the increasing violations of freedom of religion and belief leave s the question, what causes this trend to increase? As well as what factors are causing the rapid growth of religion-based identity politics and religious fundamentalism in Indonesia? The analytical framework for the above questions can be answered from how Indonesia places religion in its relation with the state.

If we look backward, the fall of the New Order which was marked by the emergence of democratization in all aspects was accompanied by the weakening of the state in people's lives. Decentralization makes new local powers emerge into the public sphere and collaborate with capital forces, thus giving rise to the dominance of private interests in the public sphere. On the other hand, communal interests based on religious or ethnic identity have also emerged to fill the void of the public sphere (after the weakening of the state), so that due to the absence of direct public access to the state, only two options remain. Market fundamentalism or religious fundamentalism. ${ }^{40}$

In this context, many Islamic organizations with a "jihadist" pattern emerged, both from local-traditional contexts and as agents of the Transnational-Islamic movement (Hizbut Tahrir, Islamic State of Iraq and Syria) with anti-secularism, anti-liberalism, and queuing pluralism characteristics. With their sectarian and exclusive character, these movements construct their political and religious identity as the frontline defenders of Islam and claim to be "pure" Islam so that many Muslim groups who are socio-economically marginalized are provoked and also become agents of spreading the word. sectarian sentiments, anti-pluralism, racism, and exclusivism. The configuration of all of this is based on what A.E. Priyono calls "Fundamentalism Reason", the reason that considers our

39 "Big religion" such as Islam, Christianity, Jews, Judaism, Hinduism, Buddhism. Ibid, 113.

40 A.E. Priyono, "Nalar Fundamentalisme Agama di Ruang-Publik," Priyono, A.E. "Nalar Fundamentalisme Agama di Ruang-Publik," Indoprogress.Com, 21 March 2011. 
group the most correct, the most superior, the most 'pure', supremacist, and the solution to everything. ${ }^{41}$

\subsection{Functional Differentiation: An Alternative for Extreme Separation or Integration}

In this context, the development of an era is marked by the increase of sophisticated technology and communication which has a significant impact especially on the relationship between religion and the state. Some figures such as Marx, JS Mill, Comte, Spencer, and Freud consider that in the modern era the role of religion will fade. Jurgen Habermas stated that the process of advancing the age will also be followed by a process of secularization until one day religion will disappear from people's lives. Habermas assumed that with the development of modern democratic society, the function of religion in fostering social integration would be replaced by a secular communicative ratio. Habermas believes that the role of religion will be replaced by communicative actions and the consensus that results. He stated, that the expressive function and social integration that had been initiated by religion for a long time would be replaced by communicative actions. ${ }^{42}$

Whereas the authority of The Sacred will be replaced by the authority of consensus which is sought every time. ${ }^{43}$ Based on the thesis of "the death of religion", when the cold war ended, Francis Fukuyama stated that the victory of liberalism had been the end of the history of civilization and secular liberal democracy was the best political system that humans could achieve. ${ }^{44}$ There are three basic principles of secularization, namely maintaining the concept of a large gap between the "religious" and "secular" world, matters relating to religion are in the private sphere, and the privatization of religion is a conditio sine qua non in the liberal democratic system. ${ }^{45}$

Jose Casanova, a sociologist from Georgetown University, stated that secularization does not only have a single meaning but rather different meanings from one another. Secularization can be interpreted as a decline in the beliefs and practices of religious worship in modern society so that it is often interpreted as a part of the process of universal human development. ${ }^{46}$ Besides, using this thesis, secularization can also be interpreted in the form of religious privatization and is often understood as a consequence of normative modern historical tendencies, which are a

\section{Ibid.}

42 Gusti A. B. Menoh, Agama Dalam Ruang Publik. (Yogyakarta: Kanisius, 2018), 97.

43 Jurgen Habermas, The Theory of Communicative Action (Boston: Beacon Press, 1987), 77.

${ }^{44}$ Fukuyama explained that after the end of the cold war, western liberal democracy is the endpoint of mankind's ideological evolution and the final form of human government. Read more Francis Fukuyama, "The End of History," The National Interest No. 16 (1989): 4.

45 Achmad Djatmiko, "Kebangkitan Agama dan Prasangka Sekuler Dalam Kajian Hubungan Internasional," Politika 8, No. 1, April (2017): 10.

46 Jose Casanova, "The Secular and Secularism," Journal of Social Research, 76 No.4 (2009): 1051-1052. 
precondition for modern liberal democratic politics. At a certain level, secularization can also be interpreted as an effort to differentiate secular domains (state, economy, science, and technology), which by Achmad Djatmiko, usually understood as 'emancipation' from religious norms and institutions. ${ }^{47}$

However, the thesis that religion will die along with the strengthening of modernism and secularism is not supported by a strong basis of argumentation. Berger stated that when the $20^{\text {th }}$ century began, predictions of the diminishing role of religion were increasingly doubtful because of the opposite, that in most parts of the world there had been an "explosion of faith". 48 Berger further stated,

"I think what I and most other sociologists of religion wrote in the 1960s about secularization was a mistake. Our underlying argument was that secularization and modernity go hand in hand. With more modernization comes more secularization. It wasn't a crazy theory. There was some evidence for it. But I think it's wrong. Most of the world today is certainly not secular. It's very religious." 49

Regarding Berger's opinion, Rodney Stark presents several data on the criticisms of secularization theory that developed in the 20th century: First, the decline of religion as a result of secularization is only a myth. 50 Stark, quoted Tocqueville, as saying that the significance of the role of religion in the United States 150 years ago persisted, even increased. Star also pointed out that 'scientific atheism' which is believed to erode the role of religion is experiencing a backflow when viewed from the side of public trust. ${ }^{51}$ Second, referring to some of the works of sociologists, anthropologists, and historians, Stark shows that the piety of the past which is opposed to skepticism and secularism in this era is something that is not right. ${ }^{52}$ Third, instead of going through the "golden of faith" era, what happens is an increase in belief in God. ${ }^{53}$

Fourth, with regard to the relationship between religion and science, Stark quoted James Leuba's research in 1914 which stated that $41.8 \%$ (forty-one point eight percent) of scientists believed in God and prayed to

47 Djatmiko, op.cit. Casanova identified three examples that the de-privatization of religion can be justified, first, to defend modern rights and freedoms, and the existence of a democratic society itself; second, to sue secular autonomy in which, although valid, is absolute; and third, to protect raditional life from juridical interference and state administration. Compare to Jose Casanova, Public Religions in the Modern World, (Chicago: The University of Chicago Press, 1994), 6.
48
Peter
L.
Berger,
"Secularization
Falsified."

http://www.firstthings.com/article/2008/02/002-secularization-falsified

49 Peter L. Berger, "Epistemological Modesty: An Interview with Peter Berger," Christian Century, 114 No. 30 October (1997): 972.

50 Rodney Stark, “Secularization: R.I.P.," Sociology of Religion, 60 No. 3 (1999): 254.

51 Ibid.

52 Ibid., 255.

53 Stark, as he quoted from World Values Surveys on Iceland in 1990 showed that $81 \%$ (eighty one percent) of Icelanders express confidence that there is life after death, 88\% (eighty eight percent) believe humans have a soul, and 40\% (fourty percent) believe in reincarnation. Ibid., 264. 
Him, 41.5\% (forty-one point five percent) did not believe in God personally and $16.7 \%$ (sixteen points seven percent) gave definitive answers. ${ }^{54}$ Fifth, the revival of Eastern Europe after the fall of the Soviet Union in 1991, where the traditional beliefs of Eastern Europeans who were predominantly Orthodox Christians re-emerged. 55 Stark's research shows that the attendance rate of worship in Hungarian society increased from 16\% (sixteen percent) in 1981 to $25 \%$ (twenty-five percent) in 1991 . In the same study, data from people claiming to be atheists declined from 14\% (fourteen percent) to $4 \%$ (four percent), while in Russia in 1991, as many as 53\% (fifty-three percent) of the population claimed to be religious, and dropped to $37 \%$ (thirty-seven percent) in 1996. Sixth, the rise of Islam and local beliefs in Asia, among others in 1978 in Turkey, 36\% (thirty-six percent) of students believed in heaven and hell. This figure rose sharply to $75 \%$ (seventy-five percent) in 1991.56 This is interesting because Turkey since Attaturk came to power, has issued a policy regarding the strict separation between state and religion.

Looking at the data, the phenomenon that occurred at the end of the 20th century seemed to provide the same conclusion. Secularism found such strong challenges when it is faced with the fact that various events that strengthened the role of religion in political life such as liberation theology in Latin America and the Iranian Revolution led by Ayatollah Khomeini. ${ }^{57}$ Also, the strengthening of right-wing populism in the form of hatred for race and religion in various parts of the world such as America, Brazil, Austria, Hungary to France due to migrants' migration from the Middle East shows the phenomenon that reinforces the current of secularism in a reversal. Based on the facts, this research argues that the total separation between religion and politics does not produce a secular society, but rather increases religious fundamentalism.

\subsection{Balancing Indonesian Religious People and State Policy}

There are various discourses about how the actual pattern of religious and state relations in the Indonesian context. This discourse began to surface when the reformation in 1998 was marked by Suharto's resignation as president. One of the mandates of the reform is an amendment to the Indonesian Constitution. This is where the debate related to how the right relationship between religion and the state begins. ${ }^{58}$ However, the essence of the new debate that arises is the discourse among parties and Islamic groups so as not to use democracy as a governance system. ${ }^{59}$

${ }^{54}$ I believe in a God to whom one may pray in the expectation of receiving an answer.

My answer, I mean more than the subjective, psychological effect of prayer. Ibid.

55 Ibid.

56 Ibid., 256.

57 Trisno S. Sutanto, "Pancasila dan Persoalan Kebebasan Beragama atau Berkeyakinan." in Hak atas Kebebasan Beragama atau Berkeyakinan di Indonesia, ed. Alamsyah M. Dja'far and Atika Nur'aini (Jakarta: Wahid Foundation, 2016), 20.

58 Carool Kersten, Berebut Wacana Pergulatan Wacana Umat Islam Indonesia Era Reformasi. Bandung: Mizan, 2018), 146.

59 Ibid. 
Kersten also stated that, the emergence of a proposal for the Indonesian Constitution to refer to the Madinah Charter and not to the Jakarta "May 22nd" Charter which has an integral connection with the Indonesian Constitution. In addition, the emergence of community organizations such as the Hizbut Tahrir Indonesia (HTI) and the Indonesian Mujahidin Council (MMI) calling for a return to the caliphate system, at least in the Southeast Asian region, made political debate among Muslim intellectuals even more complicated, because alternative governments such as the caliphate system in question questioned the role of democracy. The role of democracy was never disputed among Islamic political parties as at the beginning of Indonesia's independence". 60

According to Luthfi Assyaukanie in Islam and the Secular State in Indonesia, stated that the interpretation of Islamic political discourse in Indonesia is part of the 'history of progress and transformation towards moderation'. Assyaukanie investigated the philosophical foundations and limitations of the three models of democratic governance in Indonesia, called the Islamic Democratic State (NDI), the Religious Democratic State (NDR), and the Liberal Democratic State (NDL). In Assyaukanie's opinion, NDI has lost its foothold since the 1980s, the fall of the new order regime provides an opportunity for its bearers to try to reclaim their Islamic demands according to law and constitution. What the NDI activists are fighting for, such as Deliar Noer (a former confidant of the Masjumi leader) and Yusril Ihza Mahendra (leader of the Crescent Star Party) is to re-enter the seven words that were deleted in the Jakarta Charter in the amendment to Article 29 of the Indonesian Constitution in 2002. ${ }^{61}$ However, due to the election 1999 The Islamic People's Party (PUI), chaired by Deliar Noer, failed to reach the threshold, and other Islamic parties such as the United Development Party and the Crescent Star Party had no more than 12\% (twelve percent) of parliamentary seats, so they failed to attract the support of other Muslim parties affiliated with Muhammadiyah and NU to pass seven words in the Jakarta Charter. ${ }^{62}$

Meanwhile, the NDR considers it is no longer necessary to form a specific Islamic government. He prefers to understand Islam as a religion of morality that is a 'transcendental ethical value for human life, not as a political theory that advocates a certain form of statehood. 63 This model is based on the philosophy that religion is a vital element in communal life that does not have to be translated into a specific form of Islamic government. The characteristic of this form is that it accepts Pancasila as the sole principle in political life, but rejects secularism as an ideology. This model is quite popular among Muslim leaders in Indonesia, such as Amien Rais and Ahmad Syafii Maarif from Muhammadiyah and Sahal Mahfudh and Ali Yafie from Nahdatul Ulama. ${ }^{64}$

\section{Ibid.}

${ }^{61}$ Luthfi Assyaukanie, Islam and the Secular State in Indonesia, (Singapore: ISEAS, 2009), 185.

62 Kersten, op.cit., 152.

63 Assyaukanie, op.cit., 103.

64 Ibid. 
While the NDL emphasizes the total separation between state and religion. This model began to be voiced by Muslim intellectuals such as Luthfi Asyyaukanie, Hamid Basyaib, and Ulil Abshar Abdalla who are members of the Liberal Islamic Network (JIL). For them, the principle of pluralism lies in the separation of the role of religion and the state. Therefore, they oppose all forms of mixing between religion and the state, whether in the form of an Islamic state campaign or re-adopting the Jakarta Charter, or all religious regulations which in this case allow the state to interfere in the religious life of Muslims. The difference between the NDR and the NDL lies in the extent to which religion must play a role in politics and government. 65

The main weakness of the NDR model is to leave certain contradictions and unresolved dilemmas in protecting the plurality of Indonesian society. 66 Therefore, if the proponents of the religious state set aside the concept of secularization, those who are in favor of liberal democracy will not only accept secularization as an innate provision but also support secularization as a whole process. ${ }^{67}$ This is one of the main issues that this research has explained before. Following Casanova, secularization is defined as the separation of church and state, a fading of religion, and privatization of religion must now be reviewed.

This research stands to consider that the thesis of the separation of religion and state must be replaced by the concept of functional differentiation between religious matters and authority with political authority (state) in the public sphere. Referring to Kuntowijoyo's opinion that religious belief cannot be used simply as a basis for making or legitimizing public decisions, but it must first be translated into secular political reasoning, this is what is called religious objectification. ${ }^{68}$

The objectification of religion emphasizes the aspect that the subjective internal values of a religion must be concreted into an objective act, meaning that the religious values contained in an act are still inherent in the act, but the public, followers of any religion can carry out the act. without having to agree on the original values. The objectification of religion is important to avoid the dominance of certain religious teachings or total secularization in the public sphere so that an equilibrium relationship will be created between the influence of religion and secularism in the public sphere.

Budhy Munawar-Rachman, a Muslim intellectual at Driyakara School of Philosophy in Jakarta, said that rather than separate religion and the state in total, the functional differentiation offers a more appropriate formula as it plays a role to distinguish the institutionalized role of religion

65 Ibid.

${ }^{66}$ Ibid., 155.

67 Given an example in this issue is that those supporters of the liberal democracy do oppose in campaigning for an Islamic state or re-adopting the late Jakarta Charter. But at the same time, to stick to their principle, they are also opposing religious-based regulations that essentially allow the state to interfere in life Muslim. Ibid., 156.

68 Kuntowijoyo, Selamat Tinggal Mitos Selamat Datang Realitas, (Bandung: Mizan, 2002),213. 
from the political function of the state. Religion can still offer basic principles of sharia as a moral foundation for public policy, but its legislation itself must be a matter of public reasoning and subject to constitutional limits and universal human rights standards. ${ }^{69}$ In this case, aspects of religious determinants that enter the space of legislation and law enforcement do not merely make Indonesia a country based on one religion (theocracy), and restrictions do not also make it a secular state, but as an effort to balance the position of religion in the public domain. The consequences will certainly be much different from the existence of the AntiBlasphemy Law which tries to construct the religious life of the community, causing a legal gap in enforcement that allows for acts of intolerance due to the inability to understand the conditions that occur in Indonesian society.

\section{CONCLUSION}

Social dynamics in Indonesia today has led to the emergence of various form of attempts to manipulate information related to religious truth in the public sphere, this situation is supported by the existence of the other social components, particularly from the juridical realm, namely the existence of the Anti-Blasphemy Law. Even though, to guarantee a balanced and beneficial relationship between religious matters and society's life in the public sphere, every effort in placing religion in such public sphere should be based on: first, knowing the interdependency relation among them and second, as a part of the first point, the way to fix the problems should also result from an interdependency solution.

All in all, this research found that the urgency of the revocation of the current anti-blasphemy as it failed to distinguish between private and public matters of the society. The law has increased social problems in society. This research, therefore, recommends the creation of a new law and all derived policies which relate to the religious practice of the society in the public sphere through a concept of functional differentiation. In practice, there is a draft law on the Protection of Inter-Religious Harmony. This law will just be beneficial to society if it is placed in a balanced form of substance and procedure. The law should also address the interdependency problems among the issue.

\section{BIBLIOGRAPHY}

\section{Book}

Adji, Oemar Seno. Perkembangan Hukum Pidana dan Hukum Acara Pidana Sekarang dan di masa jang akan Datang. Jakarta: Pantjuran Tujuh, 1984.

Assyaukanie, Luthfi. Islam and the Secular State in Indonesia. Singapore: ISEAS, 2009.

Badan Nasional Penanggulangan Terorisme. Social Media Dissemination Index. Jakarta: Badan Nasional Penanggulangan Terrorism, 2019.

69 Budhy Munawar-Rachman. Reorientasi Pembaruan Islam: Sekularisme, Liberalisme, Pluralisme, Paradigma Baru Islam Indonesia, (Jakarta: LSAF and Paramadina, 2010), 215. 
Bahar, Saafroedin, Ananda B. Kusuma \& Nannie Hudawati eds., Risalah Sidang Badan Penyelenggara Usaha Persiapan Kemerdekaan Indonesia (BPUPKI)-Panitia Persiapan Kemerdekaan Indonesia (PPKI) 28 Mei 1945-22 Agustus 1945. Ed. III. Cet. 2. Jakarta: Sekretariat Negara R.I., 1995.

Cassanova, Jose. Public Religions in the Modern World. Chicago: The Univesity of Chicago Press, 1994.

Directorate General of Islamic Education. Sistem Informasi dan Humas Seketariat Direktorat Jenderal Pendidikan Islam, Annual Report. Jakarta: Ministry of Religious Affairs, 2017.

Habermas, Jurgen. The Theory of Communicative Action. Boston: Beacon Press, 1987.

Hutagalung, Muara. Hukum Islam dalam Era Pembangunan. Jakarta: Indo Hill Co, 1985.

Kersten, Carol. Berebut Wacana Pergulatan Wacana Umat Islam Indonesia Era Reformasi. Bandung: Mizan, 2018.

Kuntowijoyo. Selamat Tinggal Mitos Selamat Datang Realitas. Bandung: Mizan, 2002.

Menoh, Gusti A. B. Agama Dalam Ruang Publik. Yogyakarta: Kanisius, 2018.

Muhtadi, Burhanuddin. Populisme Politik Identitas \& Dinamika Elektoral: Mengurai Jalan Panjang Demokrasi Prosedural. Malang: Intrans Publishing, 2019.

Nongbri, Brent. Before religion: a history of a modern concept, New Haven; London: Yale University Press, 2013.

Rachman, Budhy Munawar. Reorientasi Pembaruan Islam: Sekularisme, Liberalisme, Pluralisme, Paradigma Baru Islam Indonesia. Jakarta: LSAF and Paramadina, 2010.

Segal, Robert. "Theories of Religion." In The Routledge Companion to the Study of Religion, edited by John R Hinnels. London; New York: Routledge, 2009.

Sutanto, Trisno S. "Pancasila dan Persoalan Kebebasan Beragama atau Berkeyakinan." In Hak atas Kebebasan Beragama atau Berkeyakinan di Indonesia, edited by Alamsyah M. Dja'far and Atika Nur'aini. Jakarta: Wahid Foundation, 2016.

Tayeb, Azmil. Islamic Education in Indonesia and Malaysia: Shaping Minds, Saving Souls. Jakarta: Routledge, 2018.

Wignjodipoero, Soerojo. Pengantar dan Asas-Asas Hukum Adat. Jakarta: Haji Masagung, 1990.

\section{Journal Article}

Anggraini, Kurnia Dewi. "Penafsiran Tindak Pidana Penodaan Agama dalam Perspektif Hukum." Era Hukum: Jurnal Ilmiah Ilmu Hukum, 15, No. 2 (2017):

267-293.

http: / /dx.doi.org/10.24912/era\%20hukum.v15i2.1071

Manan, Bagir, Ali Abdurahman, and Mei Susanto. "Pembangunan Hukum Nasional Yang Religius: Konsepsi dan Tantangan dalam Negara Berdasarkan Pancasila." Jurnal Bina Mulia Hukum 5, no. 2 (2021): 176-195. https://doi.org/10.23920/jbmh.v5i2.303 
Berger, Peter L. "Epistemological Modesty: An Interview with Peter Berger." Christian Centuru 114, No. 30 (1997): 972-978.

Casanova, José. "The secular and secularisms." Social Research: An International Ouarterlu 76, no. 4 (2009): 1049-1066.

Christianto, H. "The Significant Impact of Law Number 1/PNPS/1965." Jurnal Yudisial 6, no. 1 (2013): 1-16.

Dahri, Muhammad. "Tindak Pidana Penodaan Agama Di Indonesia: Tinjauan Pengaturan Perundang-Undangan dan Konsep Hukum Islam." At-Tafahum: Journal of Islamic Law 1, no. 2 (2017).

Jatmiko, Akhmad. "Kebangkitan Agama Dan Prasangka Sekuler Dalam Kajian Hubungan Internasional." Politika: Jurnal Ilmu Politik 8, no. 1 (2017): 5-18. https://doi.org/10.14710/politika.8.1.2017.5-18

Fukuyama, Francis. "The end of history?." The national interest 16 (1989): 318.

Marshall, Paul. "The ambiguities of religious freedom in Indonesia." The Review of Faith \& International Affairs 16, no. 1 (2018): 85-96. https: / / doi.org/10.1080/15570274.2018.1433588

Mirzana, Hijrah Adhyanti. "Kebijakan Kriminalisasi Delik Penodaan Agama." Pandecta Research Law Journal 7, no. 2 (2012): 147-155. https: / / doi.org/10.15294/ pandecta.v7i2.2380

Putri, Nella Sumika. "Pelaksanaan Kebebasan Beragama di Indonesia (External Freedom) Dihubungkan Ijin Pembangunan Rumah Ibadah." Jurnal Dinamika Hukum 11, no. 2 (2011): 230-242. http: / / dx.doi.org/ 10.20884/1.jdh.2011.11.2.183

Ramdan, Aiie. "Aspek-Aspek Konstitusional Penodaan Agama Serta Pertanggungiawaban Pidananya di Indonesia." Jurnal Konstitusi 15, no. 3 (2018): 616-641. https://doi.org/10.31078/.jk1538

Sopyan, Yayan. "Menyoal kebebasan beragama dan penodaan agama di Indonesia." Jurnal Cita Hukum 3, no. 2 (2015): 295-212. http: / / dx.doi.org/10.15408/ich.v2i2.2314

Stark, Rodney. "Secularization, rip." Sociology of Religion 60, no. 3 (1999): 249-273. https://doi.org/10.2307/3711936

\section{Legal Documents}

The 1945 Constitution of the Republic of Indonesia

Indone sian Criminal Law Code

Presidential Decree No. 1/PNPS/1965 concerning the Prevention of Abuse and/or Blasphemy of Religion

Joint Ministerial Regulations No. 9 and 8 of 2006 on the Guidelines for the Implementation of Duties of Regional Heads/Deputy Heads in the Maintenance of Religious Harmony, Empowerment of Religious Harmony Forums, and Establishment of Houses of Worship

International Covenant on Civil and Political Rights.

\section{Case Law}

Semarang High Court Decision No. 98/PID/2012/ PT.SMG-Andreas Guntur Wisnu Sarsono, 2017.

Ciamis District Court Decision No. 278/Pid.Sus/2012/PN. Cms, 2012

North Jakarta District Court Decision No. 1537/ Pid.B/2016/PN.Jkt Utr-Ir. Basuki Tjahaja Purnama 


\section{Website Content}

Andreas Harsono. "Korban Penerapan Pasal Penodaan Agama di Indonesia", https://www.hrw.org/id/news/2018/10/25/323701

Badan Pusat Statistik. "Citizen Based on Region and Adopted Religion." http://bps.go.id/ . "Development Index: Information and Communication Technology (IPTIK) Indone sia". http://bps.go.id/

BBC News Indonesia. "Banding Meiliana, yang divonis penjara 1,5 tahun karena keluhkan suara azan, ditolak Mahkamah Agung", https://www.bbc.com/indone sia/indone sia-47859654 . "Hoax seputar kasus Ahok, FPI, 4 November", https://www.bbc.com/indonesia/trensosial-37843842

Berita Satu. "YLBHI: Januari-Mei 2020 Terjadi 38 Kasus Penodaan Agama" https://www.beritasatu.com/nasional/670519/ylbhi-januarimei2020-terjadi-38-kasus-penodaan-agama

Detik News. "Soal Al Maidah 51, Ahok: Saya Tak Berniat Melecehkan Ayat Suci Alquran", https://news.detik.com/berita/d-3315203/soal-almaidah-51-ahok-saya-tak-berniat-melecehkan-ayat-suci-alquran

Indonesian Internet Service Providers Association. "Penetration and Behavior of Internet User in Indonesia". Source: http: / teknopreneur.com/

Johnson Constance. "Indonesia: Constitutional Court Opens Way to Recognition of Native Faiths." http://www.loc.gov/law/foreignnews / article /indonesia-constitutional-courtopens-way-to-recognitionof-native-faiths /

Kontras. "Peradilan Sesat Tajul Muluk". https://kontras.org/2012/07/16/peradilan-sesat-tajul-muluk/

Ministry of Information and Communication. "There are 800.000 Hoaxes' Sites in Indonesia." http://kominfo.go.id/

.Ministry of Information and Communication Findings: Hoax is Most Separated in April 2019." http://kominfo.go.id/

Persekutuan Gereja-Gereja di Indonesia. "Christian School Condition in Indonesia." https://pgi.or.id

Peter L. Berger. "Secularization Falsified." www.firstthings.com/article/2008/02/002-secularization-falsified

Priyono, A.E. "Nalar Fundamentalisme Agama di Ruang-Publik," Indoprogress.Com, $21 \quad$ March 2011. https://indoprogress.com/2011/03/nalar-fundamentalisme-agamadi-ruang-publik1/

Tempo. "Begini Perjalanan Metamorfosa Lia Eden", https://nasional.tempo.co/read/672566/beginiperjalananmetamorfosa-lia-eden

Wahid Foundation. "Membatasi Para Pelanggar: Laporan Tahunan Kemerdekaan Beragama Berkeyakinan Wahid Foundation 2018." http://wahidfoundation.org/ 